University of Nebraska - Lincoln

DigitalCommons@University of Nebraska - Lincoln

2009

Significance of the Trace Fossil Zoophycos in Pliocene Deposits, Antarctic Continental Margin (ANDRILL 1B Drill Core)

Molly F. Miller

Vanderbilt University, Molly.miller@vanderbilt.edu

Ellen A. Cowan

Appalachian State University, cowanea@appstate.edu

Simon H. H. Nielsen

Florida State University

Follow this and additional works at: http://digitalcommons.unl.edu/andrillrespub

Part of the Oceanography Commons, and the Paleobiology Commons

Miller, Molly F.; Cowan, Ellen A.; and Nielsen, Simon H. H., "Significance of the Trace Fossil Zoophycos in Pliocene Deposits, Antarctic Continental Margin (ANDRILL 1B Drill Core)" (2009). ANDRILL Research and Publications. 61.

http://digitalcommons.unl.edu/andrillrespub/61

This Article is brought to you for free and open access by the Antarctic Drilling Program at DigitalCommons@University of Nebraska - Lincoln. It has been accepted for inclusion in ANDRILL Research and Publications by an authorized administrator of DigitalCommons@University of Nebraska Lincoln. 


\title{
Significance of the trace fossil Zoophycos in Pliocene deposits, Antarctic continental margin (ANDRILL 1B drill core)
}

\author{
Molly F. Miller, ${ }^{1}$ Ellen A. Cowan, ${ }^{2}$ and Simon H.H. Nielsen ${ }^{3}$ \\ 1. Department of Earth and Environmental Sciences, Vanderbilt University, Nashville, TN 37235, USA \\ 2. Department of Geology, Appalachian State University, Boone, NC 28608, USA \\ 3. Antarctic Research Facility, Florida State University, Tallahassee FL 32306-4100, USA \\ Corresponding author - Molly F. Miller, email Molly.miller@vanderbilt.edu
}

\begin{abstract}
Zoophycos is a complex three dimensional trace fossil that is abundant in deep ocean sediments worldwide, but has not been described previously from Cenozoic continental margin deposits of Antarctica. In the ANDRILL 1B core drilled through the northwest McMurdo ice shelf, Zoophycos occurs in a $17 \mathrm{~m}$ thick unit of interglacial sediments bounded above and below by glacial surfaces of erosion. This unit was deposited during the transition from the relatively warm Early Pliocene characterized by productive open waters to the cooler Late Pliocene with fluctuating subpolar ice sheets. Globally, Late Cenozoic Zoophycos are most abundant at great depths $(.1000 \mathrm{~m})$, and where sedimentation rates and TOC levels are low; the Zoophycos producer, probably a worm-like animal, was (is) a slow colonizer. Application of these preferences to the ANDRILL 1B core indicates that the Zoophycosbearing unit was deposited episodically, with sufficient time between events to allow for the slow processes of colonization and construction. The foray of Zoophycos producer into the relatively shallow ANDRILL 1B depths (200-1000 m) during the Pliocene documents "emergence" of benthic animals, supporting suggestions that the unique modern Antarctic and Southern Ocean faunas result from both "emergence" and "submergence" during the Cenozoic.
\end{abstract}

Key words: biogenic structures, continental shelf, McMurdo Sound, modern fauna

\section{Introduction}

Zoophycos is a broad type of 3-dimensional structure constructed by marine infaunal animals. Palaeontologists and geologists have noted and described the structure in rocks for over 250 years (e.g. Ha"ntzschel 1975) and it is now known from deposits ranging in age from Cambrian to Holocene (Alpert 1977, Ekdale \& Berger 1978). The basic form is a spreite (also termed "spreiten" or " lamina" ) wound around a central axis (Fig. 1). However, the morphology of the trace fossil varies widely (e.g. Wetzel \& Werner 1981, Miller 1991, Lo"wemark \& Scha"fer 2003, Bromley \& Hanken 2003), as does its size, with both maximum diameter and maximum depth ranging from a few $\mathrm{cm}$ to $.1 \mathrm{~m}$; some include small forms in a separate ichnogenus, Spirophyton (Simpson 1970; but see Ekdale 1977). This variation and complexity has resulted in diverse reconstructions of Zoophycos producing behaviour(s) (Kotake 1989, 1992, Bromley 1991, Miller \& D'Alberto 2001, Lo“wemark \& Scha"fer 2003, Olivero \& Gaillard 2007) and identification of multiple potential producers including "worms" (Seilacher 1967), echiurans (Kotake 1992), and sipunculids (Ekdale 1977, Olivero \& Gaillard 2007). Given the range in morphology and age, it is likely that over time Zoophycos has been constructed by different animals with a range of behaviours that are sufficiently similar to result in the broad Zoophycos type of structure.

Palaeozoic Zoophycos occurs in marine margin, shallow water, and deep water deposits (Chamberlain 1971, Osgood \& Szmuc 1972, Miller 1991). Mesozoic Zoophycos are reported from both shelf and deeper facies (e.g. Locklair \& Savrda 1998, Olivero 2003); Tertiary and younger Zoophycos occur predominately in deeper water deposits (e.g. Blom 1984, Manley \& Lewis 1998, Bromley \& Hanken 2003, Pervesler \& Uchman 2004).

Zoophycos is widespread and regionally abundant in Late Cenozoic bathyal and abyssal sediments of the world's oceans (Ekdale 1977, Löwemark \& Schäfer 2003), and occurs in bathyal and abyssal sediments of the Southern Ocean (e.g. Pudsey et al. 1988). In spite of the fact that the continental shelves of Antarctica are isostatically depressed $(500-1000 \mathrm{~m})$ and probably have been since development of large ice sheets in the midCenozoic (Siegert et al. 2008), Zoophycos has not been described from Antarctic shelf deposits; the single brief listing of Zoophycos does not illustrate or document occurrence of characteristic features of the trace fossil 


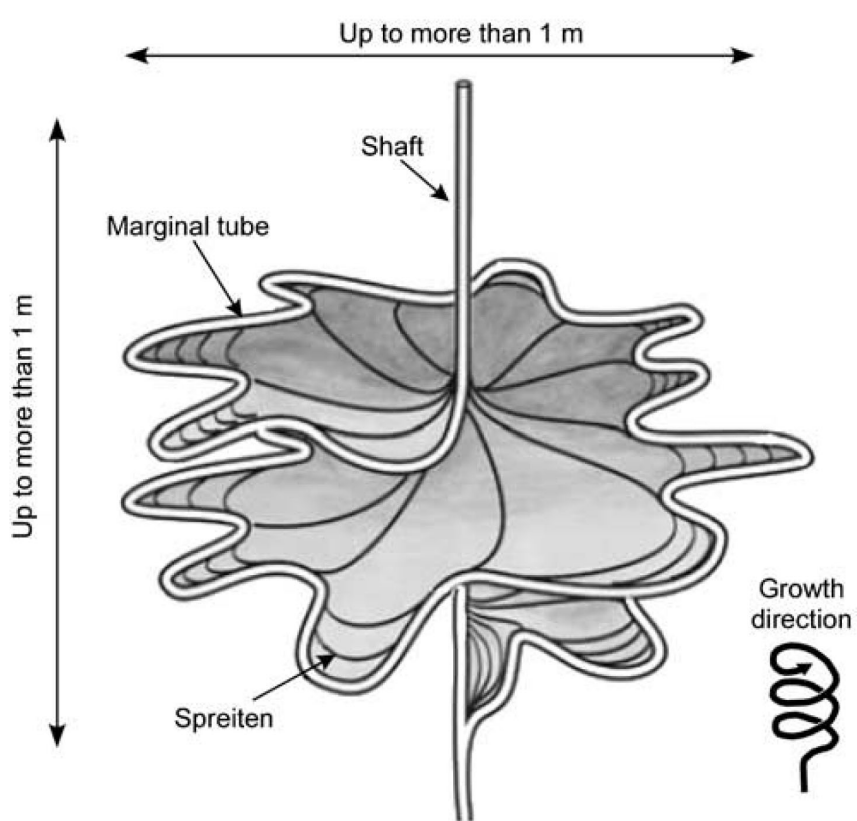

Figure 1. Major features of the trace fossil Zoophycos from Lowemark et al. (2006). The dark lines within the spreiten are the lamellae;alternativetermsforspreitenare"spreite" and"lamina".

(Fielding et al. 2000).

In this paper we describe Zoophycos from Pliocene deposits in the ANDRILL 1B core drilled under the Ross Ice Shelf at a water depth of $917 \mathrm{~m}$ in summer 2006-07 (Falconer et al. 2007). The Zoophycos occurs at ,352-354m below sea floor (mbsf) in a unit of interglacial marine sediments that is bounded above ( $346.94 \mathrm{mbsf}$ ) and below (364.18 mbsf) by glacial surfaces of erosion (Krissek et al. 2007). This interval was deposited during a major climatic transition from open water conditions in the Early Pliocene when sea surface temperatures were higher than today to cooler conditions that supported a fluctuating subpolar ice sheet during the Late Pliocene (Naish et al. 2007). Estimates of water depth range from 200 to $1000 \mathrm{~m}$. The environmental conditions of the Zoophycos-bearing unit can be interpreted at a higher resolution than would otherwise be possible by comparison with well-known Zoophycos-bearing sequences worldwide.

This occurrence of Zoophycos also has implications for the origin of the unique Antarctic benthic marine fauna. Whether the fauna developed from deep water species that migrated into shallower water ("emergence") or by expansion into deeper water of shallow water forms that survived glacial advances in protected shallowwater havens ("submergence") has been debated, and it is likely that multiple processes have been involved (e.g. Brandt et al. 2007). Paucity of a Cenozoic rock record on the continent, as well as of body fossils of macrobenthic animals in cores of Cenozoic sediments around Antarctica hampers reconstructing the biogeographic history. In the absence of shelled fossils, this Zoophycos
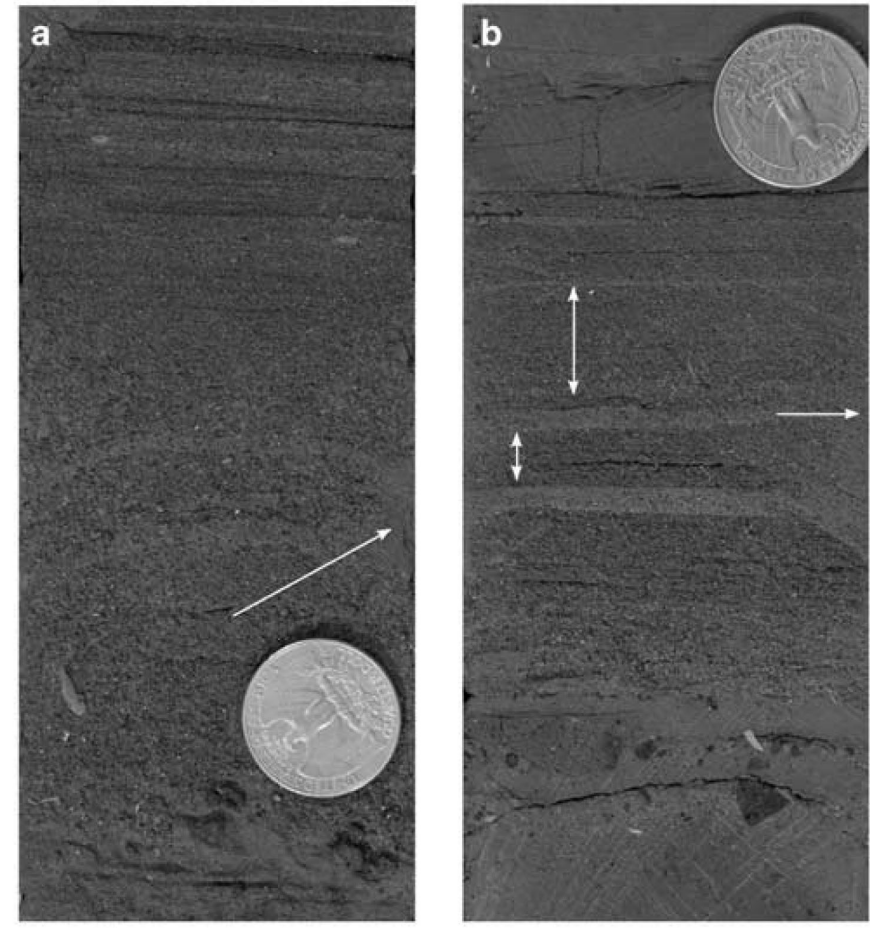

Figure 2. Zoophycos in ANDRILL 1B. a. Spreite extending outward from portion of axial structure; arrow point to axial structure. No lamellae are visible within the spreite. Top is 352.57 mbsf. b. Several spreite (vertical arrows) extending outward from axial structure at right (horizontal arrow). Note diffuse boundary of axial structure. Granules at base are volcanic rock fragments. Base of coin is at 353.29 mbsf.

suggests that organisms moved from the deep sea to the Antarctic continental shelf during the extended warm period during the Early Pliocene.

\section{Zoophycos in ANDRILL 1B: morphology and deposi- tional setting}

\section{Morphology}

Components comprising the trace fossil Zoophycos include a spreite or lamina coiled around a central axis, which commonly is an axial structure, lamellae within the lamina, and an open marginal tube (Fig. 1). Within this basic structure there is wide variation, and many specimens lack one or more of these components (e.g. Ekdale 1992, Löwemark \& Schäfer 2003, Olivero \& Gaillard 2007).

In the ANDRILL 1B core, Zoophycos is represented by eleven cross-sections of spreite. Four of these radiate off a portion of an axial structure intersected by the core at 352.62-352.64 mbsf, and two extend from a section of axial structure at 353.30-353.36 mbsf (Fig. 2). Others are isolated or in groups of two. The spreite are horizontal, gently inclined, or slightly convex. Most of the spreite are 2 to $4 \mathrm{~mm}$ thick. None have well defined lamellae. The spreite are composed of sediment that is lighter colored than the matrix; where connected to an axial 


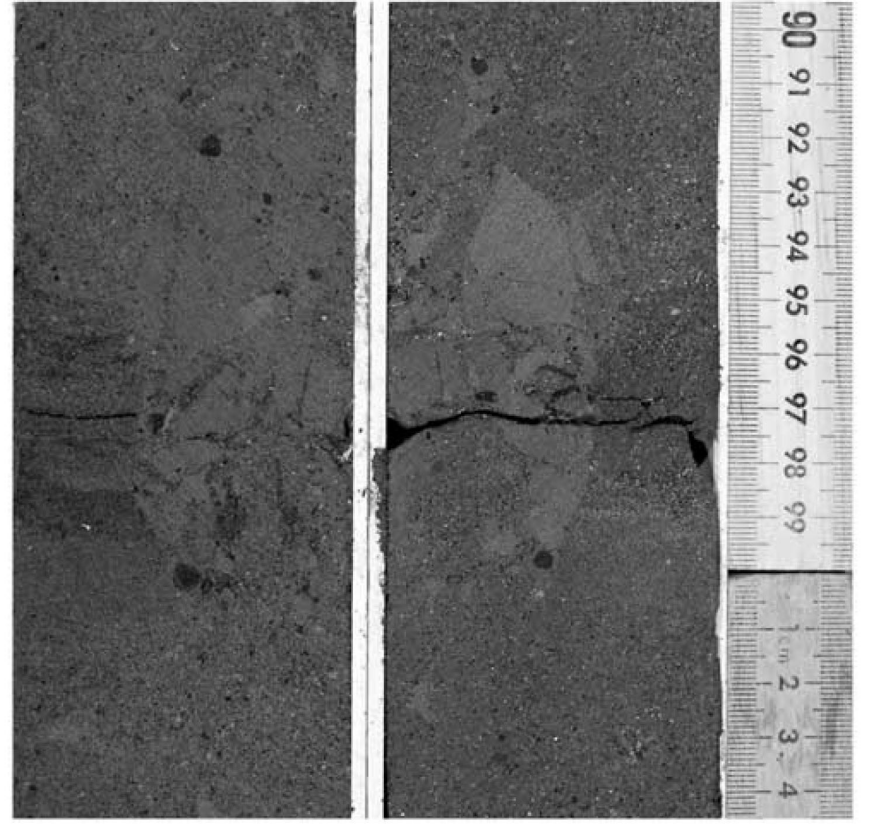

Figure. 3. Disturbed zone that may be upper part of axial structure (Fig. 1). The images are the two halves of the core from 351.89 to 352.01 mbsf; the working half is on the right, the archival half is on the left. This is, $0.5 \mathrm{~m}$ above the highest spreiten and axial structure; although its relation to the axial structure(s) in the core is not known, its location is consistent with where an upper portion of an axial structure should occur (Löwemark \& Schäfer 2003).

structure they are composed of the same material as the axial structure. In one case the spreite includes granules of volcanic rock that are similar to those occurring a few millimeters below, implying that the animal transported material upward. This has been reported elsewhere (Wetzel \& Werner 1981) although downward transport of surface material reported more commonly (Kotake 1989, Miller \& D'Alberto 2001). The axial structures are oriented obliquely and have diffuse boundaries. They are composed of the same sediment as the spreite to which they are connected. The axial structures are a minimum of $0.5 \mathrm{~mm}$ in diameter (Fig. 2).

About $0.7 \mathrm{~m}$ above the uppermost spreite (351.93 mbsf) a cone-shaped structure $1.5 \mathrm{~cm}$ in diameter cuts through layers of sandstone (Fig. 3). It has diffuse boundaries and is filled with fine-grained sediment. Although not physically connected to the spreite and axial structure that occur below, this may be a section through the upper part of an axial structure as described by Löwemark \& Schäfer (2003). If so, and if the spreite and axial structure that occur lower are all part of the same structure, the producing animal at times lived at least $1.45 \mathrm{~m}$ beneath the sediment-water interface.

\section{Depositional setting}

ANDRILL 1B recovered $1285 \mathrm{~m}$ of
core from beneath the north-west cor-
ner of the Ross Ice Shelf. The uppermost

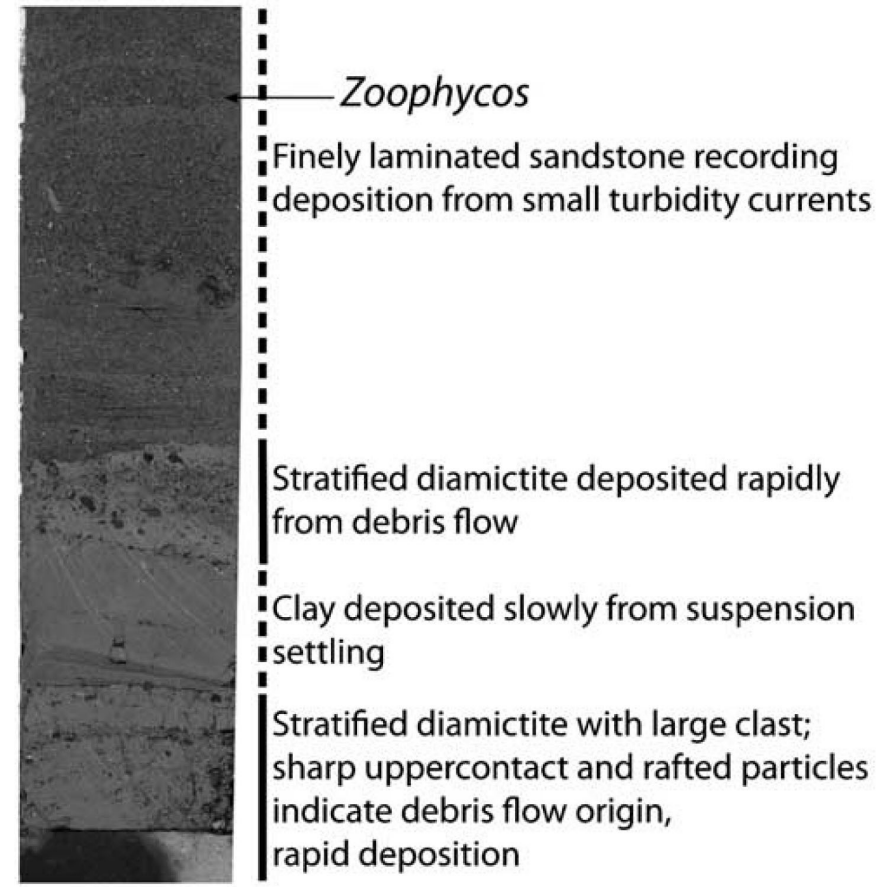

Figure. 4. Large variation in rates of deposition within a $24 \mathrm{~cm}$ thick interval (352.83-352.59 mbsf) within the Zoophycos bearing unit. Arrow points to Zoophycos in Fig. 2a. Dashed line denotes sediments deposited slowly; solid line indicates those that were deposited rapidly.

$600 \mathrm{~m}$ of core records the Pliocene to Pleistocene history of a marine-based ice shelf that waxed and waned seemingly in response to orbital cycles (Naish et al. 2007). In the Early Pliocene when sea surface temperatures were 58 higher (Whitehead \& Bohaty 2003), the ice retreated from the Ross embayment onto land in West Antarctica and diatomite accumulated under open water conditions at the ANDRILL 1B site (Naish et al. 2007). The warm period ended at,3.3 Ma as temperatures dropped and the ice sheet advanced. The time interval between ,3.5 Ma and 2.5 Ma was a period of high latitude cooling that heralded the expansion and change in style of both the West Antarctic Ice Sheet (WAIS) and East Antarctic Ice Sheet (EAIS) (Naish et al. 2007). The Zoophycos occurs in sediments deposited during the transition from icefree open marine conditions to a fluctuating subpolar ice sheet suggesting that the Zoophycos-producing animal colonized the seafloor during this transition.

The $1.5 \mathrm{~m}$ thick interval in which Zoophycos has been found (351.93-353.38 mbsf) occurs in $17.24 \mathrm{~m}$ thick unit, bounded by glacial surfaces of erosion and comprised of silty claystone, sandstone, and clast-poor muddy diamictite thought to have been deposited under proximal to distal glacimarine conditions (Krissek et al. 2007, Naish et al. 2007). Thin bedded stratified muddy diamictites below the Zoophycosbearing interval are interpreted as debris flow deposits and the sandstones as deposited from turbidity currents; both processes are associated with a proglacial setting adjacent to the ice 


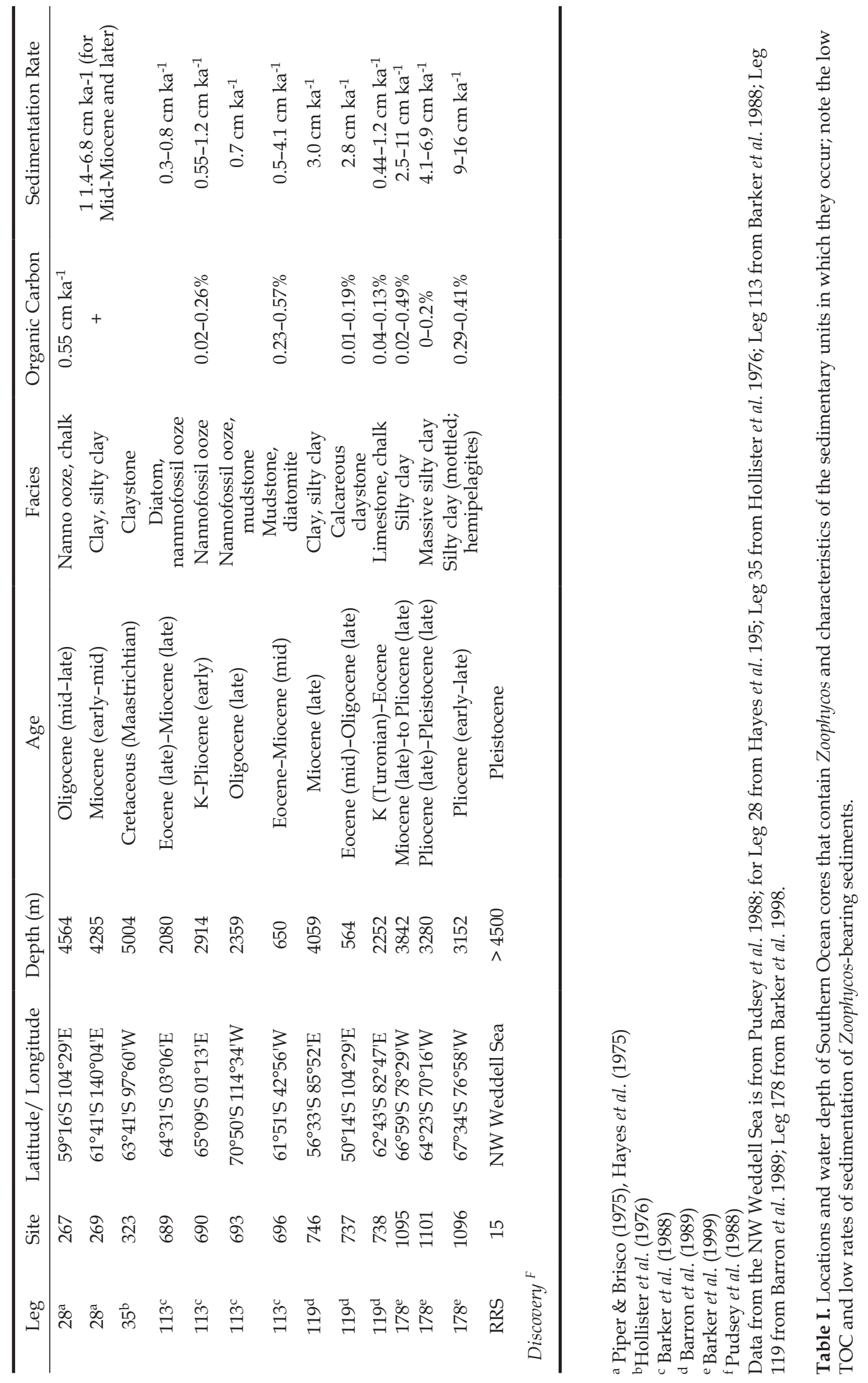


sheet (Fig. 4). Five meters above the Zoophycos bearing interval is the base of a diamictite that records the advance of the ice sheet and termination of open water conditions (Krissek et al. 2007, Naish et al. 2007).

The Zoophycos-bearing interval was deposited by sediment processes whose rates ranged from high to low (Fig. 4). Debris flow deposits accumulated rapidly whereas silty clays settled slowly from suspension. Laminated sandstones (Fig. 4) record small turbidity currents, presumably generated by processes related to the ice sheet grounding line with submarine meltwater.

\section{Environmental distribution of Cenozoic Zoophycos}

Zoophycos is both widely distributed and locally abundant in bathyal to abyssal Cenozoic deposits. Terrestrial occurrences document the enormous size of some Zoophycos ( $>1 \mathrm{~m}$ high and in diameter; Ekdale \& Lewis 1991) and allow reconstruction of the morphology and the behavior recorded (Miller \& D'Alberto 2001, Bromley \& Hanken 2003). Commonly Zoophycos occurs in fine-grained Cenozoic limestones that were originally deposited as calcareous oozes (Miller \& D'Alberto 2001, Bromley \& Hanken 2003). In turbidite sequences Zoophycos is most abundant in the upper parts of individual turbidites and in intervening mudstones, suggesting that the producers preferred quiet water conditions (e.g. Manly \& Lewis 1998). The occurrence of a small form of Zoophycos between turbidites where these are common, and of a larger form in the part of the same succession that lacks turbidites, has been interpreted as reflecting faster growth in less stressful environments not subjected to turbidity currents (e.g. Uchman \& Demírcan 1999).

Zoophycos is also common in cores of Cenozoic oceanic sediments (e.g. Chamberlain 1975) occurring in 30 drill sites from the Caribbean, Atlantic, and Pacific oceans (Ekdale 1977), as well as from the Kerguelen Plateau (Droser \& Bottjer 1991), South China Sea (Löwemark et al. 2006), Sulu Sea (Wetzel 1984) and off the western coasts

of Africa and Portugal (Wetzel \& Werner 1981, Löwemark \& Schäfer 2003). Zoophycos is restricted to water depths $>1000 \mathrm{~m}$. Its recognition is enhanced by radiography; it was found in $37 \%$ of 382 archived cores of upper Cenozoic sediments from the world oceans (Löwemark \& Schäfer 2003). As noted from terrestrial occurrences (Ekdale 1992), Zoophycos is a deep tier trace fossil produced up to a metre beneath the sedimentwater interface. An age difference of $9 \mathrm{ka}$ has been found between the sediment within the Zoophycos spreite and the surrounding sediment (Leuschner et al. 2002). Complex structure within the axial shaft is interpreted to indicate that the Zoophycos structures are occupied for a long time, implying that the producer is long-lived.

Zoophycos occurs in sediments deposited slowly (e.g.
< 20 cm ka-1; Wetzel \& Werner 1981) and is reported from hemipelagites with rates of sedimentation ranging from $<5 \mathrm{cmka}^{-1}$ to $20 \mathrm{~cm} \mathrm{ka-1}$ (Stow \& Tabrez 1998). Its peak abundance in the South China Sea is where rates of deposition are $<5 \mathrm{cmka}^{-1}$; this is consistent with its documented association with omission surfaces (Ekdale \& Lewis 1991). Although typically occurring in muds and oozes, Zoophycos also has been found in slumped sediments and deposits containing ice rafted debris (IRD), as well as commonly in turbidites (Löwemark \& Schäfer 2003).

The Zoophycos producers' preference for sediments with moderate to relatively low total organic carbon (TOC) is well documented $(<1.5 \%$ TOC Wetzel \& Werner 1981; 0.3-0.7\% TOC Löwemark et al. 2006), as is its apparent predilection for episodic rather than continual delivery of food resources. In some areas such as the South China Sea its abundance roughly tracks glacial-interglacial cycles; this is attributed to climatedriven, interrelated changes in monsoons, ocean currents, upwelling and productivity ( Löwemark et al. 2006). Conditions inimical to the Zoophycos producer(s) include high rates of sedimentation $(.20 \mathrm{~cm}$ ka- 1$)$, sandy substrates, substrates with large amounts of IRD or high TOC (.2\% TOC), and low levels of dissolved oxygen (Fu \& Werner 1994).

\section{Zoophycos in the Southern Ocean}

Zoophycos has been reported from cores taken at depths of $>3000 \mathrm{~m}$ off of the Antarctic Peninsula, where it occurs in the upper parts of turbidites and massive muds ranging in age from Early Pliocene to Late Pleistocene (ODP Leg 178, sites 1095, 1096, 1101; Table I). It has also been reported from hemipelagic deposits 200-300 ka in age recovered from a depth of . 4500m the north-western Weddell Sea (Pudsey et al. 1988), as well from Cretaceous to Miocene sediments in the Weddell Sea and between Prydz Bay and the Kerguelen Plateau (Table I). However, it is not ubiquitous in the cores from sites drilled on DSDP Legs 28 (Ross Sea) and 35 (Bellingshausen Sea), or ODP Leg 113 (Weddell Sea) and 119 (Prydz Bay).

Zoophycos has not been documented to occur in Antarctic continental shelf deposits, in spite of the great depth (mean $\sim 500 \mathrm{~m}$ ) and proximity to occurrences in the Southern Ocean. It has been mentioned as occurring in Oligocene deposits of the CRP 2/2a cores, but not illustrated or described morphologically (Fielding et al. 2000). The core description did not list the trace fossil; M. Miller perused core interval containing the reported Zoophycos and noted no well-defined structures similar to the Zoophycos in the ANDRILL 1B. Shelf deposits have been extensively investigated (e.g. Dunbar et al. 1989, Anderson 1999, Domack et al. 1999) so if Zoophycos were common, it probably would have been described. Reasons for its presumed absence or rarity are not known 
but may include one or more of the following:

1) Rate of accumulation of siliceous ooze is too high. Silicious ooze is accumulating all around Antarctica except in the Weddell Sea (Anderson 1999); accumulation rate in the Ross Sea reaches $250 \mathrm{~cm} \mathrm{kyr}^{-1}$ in coastal basins but is lower seaward (DeMaster et al. 1996).

2) Total organic carbon is too high. In McMurdo Sound, average TOC at depths below $600 \mathrm{~m}$ are $1.5 \%$ and are as high as 3.5\% (Dunbar et al. 1989), which exceed TOC levels of sediment in which Zoophycos is abundant.

3) Current is too strong, substrate too coarse. Irregular topography coupled with bottom currents results in current-winnowed substrates on banks and slopes which are coarser than the Zoophycos producers' preferred low-energy mud-dominated habitat (Taviani et al. 1993).

4) Too much IRD. IRD is accumulating today, particularly near the coast. In addition, glacial advance during the LGM in the Ross Sea and elsewhere removed soft sediment, leaving poorly sorted glacial deposits that subsequently have been blanketed with a veneer of ooze (Domack et al. 1998, 1999, Shipp et al. 1999).

5) Disruption by ice scour is too common. Iceberg scour disturbs the Antarctic shelf to depths $>500 \mathrm{~m}$. It is estimated that every square meter of the Antarctic shelf is disturbed by ice once every 340 years (Gutt 2001), a level of disturbance that may be inimical to the Zoophycos producers.

\section{ZOOPHYCOS constrains Pliocene conditions and Cli- mate in ANDRILL 1B core}

On a large scale, the Zoophycos-bearing unit in the ANDRILL 1B core represents an environmental window of opportunity between the relatively warm Early Pliocene whose productive open ocean conditions potentially led to TOC levels too high for the Zoophycos producers and the much cooler Late Pliocene during which persistent glaciation and accumulation of IRD would have been inimical to the animals. The $17 \mathrm{~m}$ thick heterolithic unit contains neither biosiliceous material signaling high productivity nor large quantities of IRD, although it is sandwiched between overlying biosiliceous diamictite and an underlying unit of intermixed diatomite and biosiliceous diamictite and mudstsone that caps a $.75 \mathrm{~m}$ thick unit of diatomite (Krissek et al. 2007). These favorable conditions for the Zoophycos producers must have been extant for an extended period for them to colonize the ANDRILL 1B site. Early Pliocene ice free conditions probably allowed long-term migration of the Zoophycos producer toward the continent, but this and colonization of sediments were most likely slow processes; at present both Antarctic and deep sea faunas are characterized by slow rates of dispersal and thus of colonization (Lipps \& Hickman 1982).
The Zoophycos-bearing interval falls within a welldated and complete stratigraphic window from 440-280 mbsf (-3.6-3.2myr) in ANDRILL 1B that is comprised of numerous advance/retreat cycles (Naish et al. 2007). Zoophycos producers were slow colonizers that preferred stable environments; its presence in the sequence implies that the grounding line position remained unchanged for an extended period within the cycle, further constraining the sedimentation rate.

On a smaller scale, the occurrence of Zoophycos provides information about the frequency of the debris flows recorded in this interval: they were sufficiently infrequent to allow colonization by and maintenance of the population of Zoophycos producers. The only quantitative estimate of time to colonize a new substrate type in the deep sea or Antarctic by Zoophycos producers of which we are aware is Wetzel's (1984) estimate of < 100-200 years in the deep sea. Given the Zoophycos producers predilection for stable conditions combined with their low rate of colonization, we infer that the debris flows and rapid sedimentation events did not occur for some period ( 100-200 years) before colonization nor during production of the trace. The Zoophycos structure may have been excavated into debris flow deposits, but these events predated construction of the Zoophycos.

The proclivity of the Zoophycos producer for habitats characterized by episodic and limited food supply also illuminates conditions during deposition. Zoophycosbearing strata in ANDRILL 1B are devoid of clear bioturbation fabrics and of discrete trace fossils formed by other deposit feeders that inhabit modern muddy sediments of the Antarctic shelf such spatangoid sea urchins, holothurians, and burrow-dwelling echiurans and whose subsurface tier activities have a high preservation potential (Smith et al. 2006). In modern shelf sediments off the Antarctic Peninsula, these animals have been shown to consume labile organic matter throughout the year, in spite of seasonal productivity in the water column, perhaps because summer phytodetritus forms a sediment food bank that deposits feeders draw on year round (Smith et al. 2006). However, in less productive settings, such as those with longer sea ice cover, or adjacent to ice shelves, food supply may be limited as well as highly seasonal. Under these conditions and similar conditions in the past, active "caching" of food resources might be the optimal survival strategy. There is growing consensus that the Zoophycos structure is used as a short-term cache for food (Miller \& D'Alberto 2001, Löwemark \& Schäfer 2003) and it has been suggested that spreite of re-ingested sediment (e.g. used cache material) are characterized by absence of lamellae (Löwemark \& Schäfer 2003); lamellae are absent from all of the ANDRILL 1B spreite. The lack of biogenic structures produced by medium to deep tier animals other than the Zoophycos producers is consistent with the interpretation that the Zoophycos-bearing sediments 
were deposited in a habitat with such limited food resources delivered so sporadically that active caching was necessary; perhaps the common shelf "sediment food bank" (Smith et al. 2006) was insufficient to support non-caching deposit feeders, leaving the Zoophycos producer as the sole infaunal deposit feeder.

\section{Origin of Antarctic fauna: relation to Zoophycos}

There is widespread agreement that the Antarctic marine fauna is unique, particularly in its lack of shellbreaking predators, high diversity and abundance of large suspension feeders, high level of endemism, prevalence of gigantism and dwarfism and of individual longevity, and tendency toward slow growth, limited reproductive dispersion, and slow colonization (Lipps \& Hickman 1982, Aronson \& Blake 2001, Gili et al. 2006).

The history and origin of the Antarctic fauna is not well understood nor is its relation to the fauna of the Southern Ocean, which only recently has been the focus of major study (e.g. Brandt et al. 2007). Components of modern benthic Antarctic faunas have been shown to have Jurassic- Cretaceous affinities (e.g. isopods, molluscs, gorgonaceans, hexactinellids; Stilwell \& Zinsmeister 1992, Gili et al. 2006) and the legacies of early Tertiary molluscs, echinoids, and polychaetes (La Meseta Formation) are represented in modern faunas (Clarke 1990, Crame 1997, Stilwell \& Zinsmeister 2000). Lack of post-Cretaceous deposits and paucity of body fossils in post-Eocene sediments on the shelf hampers reconstruction of the evolution of the benthic fauna that occurred as the climate cooled starting in the late Eocene and the fauna was isolated by the opening of the Drake Passage (Aronson \& Blake 2001).

\section{Suggested origins of the Antarctic marine fauna}

In the absence of fossil data, several scenarios for the origin of the Antarctic benthic fauna have been proposed, including that the shelf faunas migrated to deep ocean basins ("submergence" ), that deepwater faunas migrated upward to the continental shelves ("emergence" ), and that the faunas have developed largely in place (Clarke et al. 2004). Evidence for submergence comes from the distribution of genetically similar populations of Epistominella vitrea, a benthic foram that is abundant on Antarctic shelves and has an expanded depth range in the Southern Ocean (Brandt et al. 2007), from present-day occurrence in deep water of molluscs found in early Cenozoic deposits on the Antarctic Peninsula, and from the eurybathic distributions of many species, interpreted to have developed by forced retreat to deep water during ice sheet advance (Brey et al. 1996).

Development of the faunas in situ is supported by the high proportion of endemics in many groups, including pycnogonids (85\% endemics, Clarke \& Johnston 2003), gastropods (Crame 1997), and isopods (Brandt 2005). An example of emergence is provided by the large agglutinated foraminifera Astrammina triangularis which occurs at $25 \mathrm{~m}$ in western McMurdo Sound but at much greater depths elsewhere (Bowser et al. 2002). It appears that all three processes have contributed to the origin of the Antarctic benthic fauna, an interpretation based almost exclusively on inferences from distributions of modern animals with little contribution from the limited body fossil record.

\section{Contribution of Zoophycos to understanding modern Antarctic marine fauna}

Occurrence of Zoophycos in Pliocene sediments from the ANDRILL 1B core coupled with its distribution in cores of deep sea sediments both younger and older in age demonstrates convincingly that some benthic animals migrated from deep water onto the Antarctic shelf during glacial minima.

The oldest post-Palaeozoic occurrence of Zoophycos in Antarctica is from the Jurassic to Cretaceous Fossil Butte Group of Alexander Island (Antarctic Peninsula) (Taylor 1967), composed primarily of bathyal siliciclastics (Doubleday et al. 1993). Zoophycos also has been recorded from numerous deep sea cores from all sectors of the Southern Ocean (Table I) in deposits of Cretaceous and Eocene through Pleistocene age. We suspect that poor core recovery and lack of x-radiography has resulted in Zoophycos being under-reported; Zoophycos stands out in radiographs but may be difficult to see on core surfaces (Löwemark \& Schäfer 2003).

We are aware of no previously published descriptions of Zoophycos in cores of Cenozoic deposits from Ross Sea and McMurdo Sound. The single documented occurrence is that reported herein in Pliocene deposits, where the Zoophycos structure stands out in lithologic contrast with the surrounding material. More specimens may well be found in SHALDRILL, ANDRILL and other cores as more are x-rayed. Zoophycos occurs at the end of a multi-million year period of relative warmth (Naish et al. 2007) that provided time for the producer, probably a slow colonizer (Lipps \& Hickman 1982, Wetzel 1984), to migrate onto the shelf; in fact there was time for repeated migrations around the continent. We infer that the distribution of Zoophycos producers was limited to localized areas shielded from high rates of sedimentation and organic enrichment, but that seasonal influx of organic matter provided material that could be stashed in temporary caches within the Zoophycos structure (Jumars et al. 1990, Smith et al. 2006).

Significantly, Zoophycos occurs in Pliocene and Pleistocene deposits at depths $>3000 \mathrm{~m}$ off of the Antarctic Peninsula and in the Weddell Sea in sediments $200 \mathrm{ka}$ to $300 \mathrm{ka}$ (Pudsey et al. 1988). These occurrences document the continued presence of the Zoophycos producer(s) in deep sea habitats during Pliocene migration into shallower water. The subsequent history is less clear, 
with several possibilities: 1) the Zoophycos producer(s) retreated to deeper water habitats, 2) the Zoophycos producer(s) remained on the shelf, but the record of activity has been eroded, or 3) the Zoophycos producer(s) remained in isolated refuges on the shelf (e.g. Gili et al. 2006).

\section{Conclusions}

The trace fossil Zoophycos occurs as sections of spreite and axial structures in a $1.5 \mathrm{~m}$ thick interval in ANDRILL 1B core recovered from underneath the Ross Ice Shelf. It is found in debris flow and vertically accreted sediments deposited during the transition from warm, open marine conditions in the Early Pliocene to a colder Late Pliocene characterized by subpolar ice sheets. Application of known preferences of the Zoophycos producers known from worldwide occurrences to the Zoophycos in ANDRILL 1B suggests that rates of sedimentation and levels of TOC were low, and that food was delivered episodically. In spite of evidence of sea floor disturbance (e.g. debris flows, turbidity currents), the presence of Zoophycos, whose producers are slow colonizers with strong preference for stable environments indicates extended periods with little change and minimal disturbance.

Previously Zoophycos was known from Mesozoic deposits in the Antarctic Peninsula and Cenozoic deep sea deposits around Antarctica, but had never been described from continental shelf deposits. The apparent absence of Zoophycos from shelf deposits except in ANDRILL 1B near the end of an extended period of Pliocene relative warmth suggests that the producers migrated onto the shelf during climate amelioration and retreated into deeper water during cooling and ice sheet advance. Given the poor Cenozoic body fossil record of Antarctica, this occurrence of Zoophycos provides rare positive fossil evidence that components of the Antarctic benthic fauna have "emerged" into shallow water during ameliorating climate.

Acknowledgements - The ANDRILL project is a multinational collaboration between the Antarctic programs of Germany, Italy, New Zealand and the United States. Antarctica New Zealand is the project operator and developed the drilling system in collaboration with Alex Pyne at Victoria University of Wellington and Webster Drilling and Enterprises Ltd. Antarctica New Zealand support the drilling team at Scott Base; Raytheon Polar Services supported the science team at McMurdo Station and the Crary Science and Engineering Laboratory. The ANDRILL Science Management Office at the University of Nebraska-Lincoln provided science planning and operational support. Scientific studies are jointly supported by the US National Science Foundation, NZ Foundation for Research, Science and Technology and the Royal Society of New Zealand Marsden Fund, the Italian Antarctic Research Programme, the German Research Foundation (DFG) and the Alfred Wegener Institute for Polar and Marine Research. We thank Steve
Petrushak for help accessing cores at Antarctic Research Facility, Florida State University. Marco Taviani and Chuck Savrda made valuable suggestions on an earlier version of the paper.

\section{References}

Alpert, S.P. 1977. Trace fossils and the basal Cambrian boundary. In Crimes, T.P. \& Harper, J.C., eds. Trace fossils 2. Geological Journal Special Issue, 9, 1-8.

Anderson, J.B. 1999. Antarctic marine geology. Cambridge: Cambridge University Press, 289 pp.

Aronson, R.B. \& Blake, D.B. 2001. Global climate change and the origin of modern benthic communities in Antarctica. American Zoologist, 41, 27-39.

Barker, P.E., Kennett, J.P., et al. 1988. Proceedings of the Ocean Drilling Program, Initial Reports, 113, $785 \mathrm{pp}$.

Barker, P.F., Camerlenghi, A., Acton, G.D., et al. 1999. Proceedings of the Ocean Drilling Project, Initial Reports, 178. www. odp.tamu.edu/ publications/178_IR/178TOC.HTM

Barron, J., Larsen, B., et al. 1989. Proceedings of the Ocean Drilling Program, Initial Reports, 119, 10.2973/odp.proc.ir.119.1989.

Blom, W.M. 1984. Stratigraphy and sedimentology of Tokomaru Formation (Late Miocene-Early Pliocene), eastern Raukumara Peninsula, New Zealand. New Zealand Journal of Geology and Geophysics, 27, 125-137.

Bowser, S.S., Bernhard, J.M., Habuäära, A. \& Gooday, A.J. 2002. Structure, taxonomy and ecology of Astrammina triangularis (Earland), an allogromiid-like foraminifer from Explorers Cove, Antarctica. Journal of Foraminiferal Research, 32, 364-374.

Brandt, A. 2005. Evolution of Antarctic biodiversity in the context of the past: the importance of the Southern Ocean deep sea. Antarctic Science, 17, 509-521.

Brandt, A., Gooday, A.J., Brandao, S.N., Brix, S., Broekeland, W., Cedhagen, T., Choudhury, M., Cornelius, N., Danis, B., De Mesel, I., Diaz, R.J., Gillan, D.C., Ebbe, B., Howe, J.A., Janussen, D., Kaiser, S., Linse, K., Malyutina, M., Pawlowski, J., Raupach, M. \& Vanreusel, A. 2007. First insights into biodiversity and biogeography of the Southern Ocean deep sea. Nature, 447, 307-311.

Brey, T., Dahm, C., Gorny, M., Klages, M., Stiller, M. \& Arntz, W.E. 1996. Do Antarctic benthic invertebrates show an extended level of eurybathy? Antarctic Science, 8, 3-6.

Bromley, R.G. 1991. Zoophycos: strip mine, refuse dump, cache or sewage farm? Lethaia, 24, 460-462.

Bromley, R.G. \& Hanken, N.-M. 2003. Structure and function of large, lobed Zoophycos, Pliocene of Rhodes, Greece. Palaeogeography, Palaeoclimatology, Palaeoecology, 192, 79-100.

Chamberlain, C.K. 1971. Morphology and ethology of trace fossils from the Ouchhita Mountains, southeastern Oklahoma. Journal of Paleontology, 45, 212-246.

Chamberlain, C.K. 1975. Trace fossils in DSDP cores of the Pacific. Journal of Paleontology, 49, 1074-1096.

Clarke, A. 1990. Temperature and evolution: Southern Ocean cooling and the Antarctic marine fauna. In Kerry, K.R. \& Hempel, G., eds. Antarctic ecosystems: ecological change and conservation. Berlin: Springer, 9-22.

Clarke, A. \& Johnston, N.M. 2003. Antarctic marine benthic diversity. Oceanography and Marine Biology: an Annual Review, 41, 47-114.

Clarke, A., Aronson, R.B., Crame, J.A., Gili, J.-M. \& Blake, D.B. 2004. Evolution and diversity of the benthic fauna of the Southern Ocean continental shelf. Antarctic Science, 16, 
$559-568$.

Crame, J.A. 1997. An evolutionary framework for the Polar Regions. Journal of Biogeography, 24, 1-9.

DeMaster, D.J., Ragueneau, O. \& Nittrouer, C.A. 1996. Preservation efficiencies and accumulation rates for biogenic silica and organic C, N, and P in high-latitude sediments: the Ross Sea. Journal of Geophysical Research, 101, 18 501-18 518.

Domack, E.W., Jacobsen, E.A., Shipp, S. \& Anderson, J.B. 1999. Late Pleistocene-Holocene retreat of the West Antarctic icesheet system in the Ross Sea: Part 2. Sedimentologic and stratigraphic signature. Geological Society of America Bulletin, 111, 1517-1536.

Domack, E.W., O’Brien, P., Harris, P., Taylor, F., Quilty, P.G., DeSantis, L. \& Raker, B. 1998. Late Quaternary sediment facies in Prydz Bay, East Antarctica and their relationship to glacial advance onto the continental shelf. Antarctic Science, 10, 236-246.

Doubleday, P.A., MacDonald, D. \& Nell, P.A.R. 1993. Sedimentology and structure of the trench-slope to forearc basin transition in the Mesozoic of Alexander Island, Antarctica. Geological Magazine, 130, 737-754.

Droser, M.L. \& Bottjer, D.J. 1991. Trace fossils and ichnofabrics in Leg 119 cores. In BARRON, J.A., et al. eds. Proceedings of the Ocean Drilling Program, Leg 119, Scientific Results, 119, 635-641.

Dunbar, R.B., Leventer, A.R. \& Stockton, W.L. 1989. Sedimentation in McMurdo Sound, Antarctica. Marine Geology, 85, 155-179.

Ekdale, A.A. 1977. Abyssal trace fossils in worldwide Deep Sea Drilling Project cores. In Crimes, T.P. \& Harper, J.C., eds. Trace fossils 2. Geological Journal Special Issue, 9, 163-182.

Ekdale, A.A. 1992. Muckraking and mudslinging: the joys of deposit feeding. In Maples, C.G. \& West, R.C., eds. Trace fossils. Paleontological Society Short Course, no. 5, 163-182.

Ekdale, A.A. \& Berger, W.H. 1978. Deep-sea ichnofacies: modern organism traces on and in pelagic carbonates of the western equatorial Pacific. Palaeogeography, Palaeoclimatology, Palaeoecology, 23, 263-278.

Ekdale, A.A. \& Lewis, D.W. 1991. The New Zealand Zoophycos revisited: morphology, ethology, and paleoecology. Ichnos, 1, 183-194.

Falconer, T., Pyne, A. \&, Levy, R., Olney M. \& ANDRILL-MIS Science Team. 2007. Operations overview for the ANDRILL McMurdo ice shelf project, Antarctica. Terra Antarctica, 14, 131-140.

Fielding, C., Naish, T., Woolfe, K. \& Lavelle, M. 2000. Facies analysis and sequence stratigraphy of CRP-2/2A, Victoria Land Basin, Antarctica. Terra Antarctica, 7, 323-338.

Fu, S. \& Werner, F. 1994. Distribution and composition of biogenic structures on the Iceland-Faeroe Ridge: relation to different environments. Palaios, 9, 92-101.

Gili, J.-M., Arntz, W.E., Palanques, A., Orejas, C., Clarke, A., Dayton, P.E., Isla, E., Teixidó, N., Rossi, S. \& LopezGonzález, P.J. 2006. A unique assemblage of epibenthic sessile suspension feeders with archaic features in the highAntarctic. Deep-Sea Research II, 53, 1029-1052.

Gutt, J. 2001. On the direct impact of ice on marine benthic communities, a review. Polar Biology, 24, 553-564.

Häntzschel, W. 1975. Trace fossils and problematica. In Teichert, C., ed. Treatise on Invertebrate Paleontology, Part W, Miscellanea, Supplement 1. Lawrence, KS: Geological Society of America and University of Kansas Press, 269 pp.
Hayes, D.E \&., Frakes, L.A. \& Shipboard Scientific Party. 1975. Initial Reports of the Deep Sea Drilling Project, 28, 1017 pp.

Hollister, C.D., Craddock, C., et al. 1976. Initial Reports of the Deep Sea Drilling Project, 35. Washington, DC: Government Printing Office, $930 \mathrm{pp}$.

Jumars, P.A., Mayer, L.M., Deming, J.W., Baross, J.A. \& Wheatcroft, R.A. 1990. Deep-sea deposit feeding strategies suggested by environmental and feeding constraints. Philosophical Transactions of the Royal Society of London, A331, 85-101.

Kotake, N. 1989. Paleoecology of the Zoophycos producers. Lethaia, 22, 327-341.

Kotake, N. 1992. Deep sea echiurans: possible producers of Zoophycos. Lethaia, 25, 311-316.

Krissek, L., Brown, G., Carter, L., Cowan, E., Dunbar, G., McKay, R., Naish, T., Powell, R. \& Reed, J. 2007. Sedimentology and stratigraphy of AND-1B Core, ANDRILL McMurdo Ice Shelf Project, Antarctica. Terra Antarctica, 14, 185-222.

Leuschner, D.C., Sirocko, F., Grootes, P.M. \& Erlenkeuser, H. 2002. Possible influence of Zoophycos bioturbation on radiocarbon dating and environmental interpretation. Marine Micropaleontology, 46, 111-126.

Lipps, J.H. \& Hickman, C.S. 1982. Origin, age, and evolution of Antarctic and deep-sea faunas. In Ernst, W.G. \& Morin, J.G., eds. The environment of the deep sea. Englewood Cliffs, NJ: Prentice Hall, 325-356.

Locklair, R.E. \& Savrda, C.E. 1998. Ichnology of rhythmically bedded Demopolis chalk (Upper Cretaceous, Alabama): implications for paleoenvironment, depositional cycle origins, and tracemaker behavior. Palaios, 13, 423-438.

Löwemark, L. \& Schäfer, P. 2003. Ethological implications from a detailed X-ray radiograph and $14 \mathrm{C}$ study of the modern deep-sea Zoophycos. Palaeogeography, Palaeoclimatology, Palaeoecology, 192, 101-121.

Löwemark, L., LIN, H.-L. \& Sarnthein, M. 2006. Temporal variations of the trace fossil Zoophycos in a $425 \mathrm{ka}$ long sediment record from the South China Sea: implications for the ethology of the Zoophycos producer. Geological Magazine, 143, 105-114.

Manley, R. \& Lewis, D.W. 1998. Ichnocoenoses of the Mount Messenger Formation, a Miocene submarine fan system, Taranaki Basin, New Zealand. New Zealand Journal of Geology and Geophysics, 41, 15-33.

Miller, M.F. 1991. Morphology and distribution of Paleozoic Spirophyton and Zoophycos: implications for the Zoophycos ichnofacies. Palaios, 6, 410-425.

Miller III, W. \& D'Alberto, L. 2001. Paleoethologic implications of Zoophycos from Late Cretaceous and Paleocene limestones of the Venetian prealps, northeastern Italy. Palaeogeography, Palaeoclimatology, Palaeoecology, 166, 237-247.

Naish, T., Powell, R.D., Barrett, P.J., Levy, R.H., et al. 2007. Cenozoic climate history of the Ross Embayment from the AND-1B Drill Hole: culmination of three decades of Antarctic margin drilling. In Cooper, A.K., ed. Antarctica: a keystone in a changing world. USGS Open-File Report 1007-1047, 71-82.

Olivero, D. 2003. Early Jurassic to Late Cretaceous evolution of Zoophycos in the French subalpine basin (southeastern France). Palaeogeography, Palaeoclimatology, Palaeoecology, 192, 59-78.

Olivero, D. \& Gaillard, C. 2007. A constructional model for 
Zoophycos. In Miller III, W., ed. Trace fossils concepts, problems, prospects. Amsterdam: Elsevier, 466-477.

Osgood JR, R.G. \& Szmuc, E. 1972. The trace fossil Zoophycos as an indicator of water depth. Bulletin of American Paleontology, 62, 1-22.

Pervesler, P. \& Uchman, A. 2004. Ichnofossils from the type area of the Grund Formation (Miocene, Lower Badenian) in northern lower Austria. Geologica Carpathica, 55, 103-110.

Piper, D.J.W. \& Brisco, C.B. 1975. Deep water continental margin sedimentation, DSDP Leg 28 Antarctica. Initial Reports of the Deep Sea Drilling Project, 28, 727-755.

Pudsey, C.J., Barker, P.F. \& Hamilton, N. 1988. Weddell Sea abyssal sediments: a record of Antarctic bottom water flow. Marine Geology, 81, 289-314.

Shipp, S., Anderson, J.B. \& Domack, E.W. 1999. Late Pleistocene-Holocene retreat of the West Antarctic ice-sheet system in the Ross Sea: Part 1. Geophysical results. Geological Society of America Bulletin, 111, 1486-1516.

Seilacher, A. 1967. Bathymetry of trace fossils. Marine Geology, 5, 413-428.

Siegert, M.J., Barrett, P.J., Deconto, R., Dunbar, R., Cofaigh, C.O., Passchier, S. \& Naish, T. 2008. Recent advances in understanding Antarctic climate evolution. Antarctic Science, 20, 313-325.

Simpson, S. 1970. Notes on Zoophycos and Spirophyton. In Crimes, T.P. \& Harper, J.C., eds. Trace fossils. Geological Journal Special Issue, 3, 475-497.

Smith, C.R., Mincks, S. \& DeMaster, D.J. 2006. A synthesis of benthopelagic coupling on the Antarctic shelf: food banks, ecosystem inertia and global climate change. Deep-Sea Research II, 53, 875-894.

Stilwell, J.D. \& Zinsmeister, W.J. 1992. Molluscan systematics and biostratigraphy, Lower Tertiary La Meseta Formation, Seymour Island, Antarctic Peninsula. Antarctic Research Series, 55, 1-192.

Stilwell, J.D. \& Zinsmeister, W.J. 2000. Paleobiogeographic synthesis of the Eocene macrofauna from McMurdo Sound, Antarctica. Antarctic Research Series, 76, 365-372.

Stow, D.A.V. \& Tabrez, A.R. 1998. Hemipelagites: processes, facies and model. In Stoker, M.S. \& Evans, D., eds. Geologic processes of continental margins: sedimentation, mass wasting and stability. Geological Society Special Publication, 29, 317337. .

Taviani, M., Reid, D.F. \& Anderson, J.B. 1993. Skeletal and isotopic composition and paleoclimatic significance of Late Pleistocene carbonates, Ross Sea, Antarctica. Journal of Sedimentary Petrology, 63, 84-90.

Taylor, B.J. 1967. Trace fossils from the Fossil Bluff Series of Alexander Island. British Antarctic Survey Bulletin, no. 13, 1-30. Sedimentological Implications of Zoophycos 617 http://journals.cambridge.org

Uchman, A. \& Demírcan, H. 1999. A Zoophycos group trace fossil from Miocene flysch in southern Turkey: evidence for a U-shaped causative burrow. Ichnos, 6, 251-259.

Wetzel, A. 1984. Bioturbation in deep-sea fine-grained sediments: influence of sediment texture, turidite frequency and rates of environmental change. In Stow, D.A.V. \& Piper, D.J.W., eds. Fine grained sediments: deep water processes and facies. Oxford: Blackwell Scientific Publications, 595608.

Wetzel, A. \& Werner, F. 1981. Morphology and ecological significance of Zoophycos in deep-sea sediments off NW Africa.
Palaeogeography, Palaeoclimatology, Palaeoecology, 32, 185-212. Whitehead, J.M. \& Bohaty, S.M. 2003. Pliocene summer sea surface temperature reconstruction using silicoflagellates from Southern Ocean OCP Site 1165. Paleoceanography, 18, $1-11$. 